POLIIICAL ECONOMY RESEARCH INSIITUTE

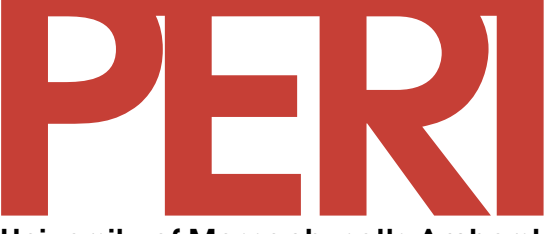

University of Massachusetts Amherst

The Economics of Civil War:

The Case of the Democratic Republic of Congo

\author{
Léonce Ndikumana \\ Kisangani Emizet
}

2003

10th floor Thompson Hall University of Massachusetts Amherst, MA, 01003-7510 Telephone: (413) 545-6355 Facsimile: (413) 545-2921

Email:peri@econs.umass.edu Website:

hHp://www.umass.edu/peri/

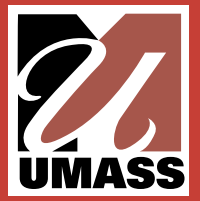




\title{
The Economics of Civil War: The Case of the Democratic Republic of Congo
}

July 1, 2003

Léonce Ndikumana

Department of Economics

University of Massachusetts

Amherst, MA 01003

Tel: (413) 545-6359; Fax: (413) 545-2921

Email: ndiku@econs.umass.edu; Web: http://www-unix.oit.umass.edu/ ndiku

\author{
Kisangani Emizet \\ Department of Political Science \\ Kansas State University \\ Manhattan, KS 66506
}

Tel: (785) 532-0447; Fax: (785) 532-532-2339

Email: emizetk@ksu.edu; Web: http://www-personal.ksu.edu/ emizetk

\begin{abstract}
This study analyzes the causes of civil wars in the Congo since independence and investigates how the Congo case fits the model of civil war proposed by Collier and Hoeffler. Five conclusions arise from this case study. First, the level and growth rate of national income increased the risk of war by reducing the cost of organizing rebellions and the government's ability to counteract the rebellions. Second, while regional ethnic dominance served as a basis for mobilization of rebellions, ethnic antagonism was also an obstacle to the expansion of civil wars beyond the province of origin. Third, while natural resource dependence was a significant determinant of civil wars in the DRC, it is the geographic concentration of natural resources and their unequal distribution that made the Congo particularly prone to civil war. Fourth, the government's ability to counteract rebellions depended more on external support than on the government's military and economic capacity. Fifth, discriminatory nationality laws, disruptions in the ethnic balance of the eastern region caused by the influx of Rwandan Hutu refugees in 1994, and shared ethnicity between rebels and neighboring regimes-variables which are not included in the Collier-Hoeffler model-were significant determinants of the outbreak of civil wars in the 1990s.
\end{abstract}

Paper prepared for the Yale University/World Bank project on "The Economics and Politics of Civil Wars."

Acknowledgments: The authors are grateful for helpful comments and suggestions from Paul Collier, Frank Holmquist, Janvier Désiré Nkurunziza, Nils Petter Gleditsch, and Nicholas Sambanis. They would like to thank Anke Hoeffler, who supplied crosscountry data. 


\section{Introduction}

The Democratic Republic of Congo (DRC) has experienced several rebellions and wars since its independence in 1960. These wars share common features while exhibiting important differences with regard to their causes. The purpose of this chapter is to analyze the causes of eight wars in the Congo and to investigate how the Congo case fits the core Collier-Hoeffler model of civil war (Collier and Hoeffler 1998, 2001, 2002). ${ }^{1}$

Five conclusions arise from this case study. First, the level and growth rate of income reduced the cost of organizing rebellions and, to a limited extent, the government's ability to counteract the rebellions. Second, while regional ethnic dominance served as a basis for mobilization of civil wars, ethnic antagonism was also an obstacle to the expansion of these wars beyond the province of origin. Third, while natural resource dependence, as predicted by the Collier-Hoeffler model, was a significant determinant of civil wars in the $\mathrm{DRC}$, it is not dependence per se that motivated the conflicts, but rather the geographic concentration of natural resources and their unequal distribution. Fourth, the government's ability to counteract rebellions depended more on external support than on the government's military and economic capacity. Fifth, discriminatory nationality laws, disruptions in the ethnic balance of the eastern region caused by the influx of Rwandan Hutu refugees in 1994, and shared ethnicity between rebels and neighboring regimes — variables which are not included in the Collier-Hoeffler model—were significant determinants of the outbreak of civil wars in the 1990s.

We organize the study as follows. The next section analyzes eight civil wars that occurred in the DRC since 1960. Section 3 examines the performance of the Collier- 
Hoeffler model in predicting the Congo's wars and distinguishes cases that fit the model from those that remain puzzles to be explained. ${ }^{2}$ Section 4 draws conclusions based on these findings. We conclude that some factors in the Collier-Hoeffler model are important in explaining wars in the Congo, while a number of critical determinants of the timing and location of rebellions are missing from the model.

\section{The wars in the Congo since 1960}

The main features of the eight wars discussed in this section are summarized in Table 1. Below, we provide an analysis of the context and the causes of these wars.

\subsection{The Katanga secession war: 11 July 1960 - 14 January 1963}

\section{(i) The movement for Katangan autonomy}

The Katangan secessionist movement dates from the colonial era. Under the Congo Free State, Katanga was administered by the privately owned Comité Spécial du Katanga until 1910 when its administration was transferred to a vice governor general (Meditz and Merrill 1994). In 1933, administrative reorganization brought Katanga in accordance with the other provinces under the central colonial administration despite strong resentment by Katanga's European residents. Because of the diversity and abundance of its natural riches, Katanga attracted a large number of Europeans and accounted for over 30 percent of the total non-African population in the Congo in 1955 (see Table A1 in the appendix). However, only seven percent of these $(2,310$ out of 31,847 ) could be regarded as genuine settlers, the rest consisted of temporarily employed civil servants, industrialists, technicians, and missionaries (Lemarchand 1964: 233-234). 
The province is the sole producer of copper (70 percent of national production) and cobalt. At independence, Katanga accounted for 75 percent of the Congo's mineral output, about 50 percent of total national resources, and roughly 20 percent of the government's total budgetary expenditures. The province is also the home of the dominant ethnic groups of the Lunda, Baluba of Katanga, and Bayeke, who historically claimed to be unfairly represented in the central government. The other important feature of the province is the early rapid development of a large urban (non-agricultural) wageearning population ( $36 \%$ in 1959 , see Table A1), which served as a base for political mobilization by leaders of the secessionist movement.

(ii) Ethnic character of political parties in the pre-independence era

The Katangan secession war was influenced by the ethnic character of the political parties that developed in the period leading to independence. The main parties that contested power at independence were polarized along ethnic lines, except for Lumumba's Mouvement National Congolais (Congolese National Movement, MNC), which advocated national unity and transcended ethnic affiliation (Young 1965). In Katanga, the leading political force was the Confédération des Associations Tribales du Katanga (CONAKAT), created on 4 October 1958, whose mission was to defend the interests of the "authentic Katangans" (mainly the Lunda, Baluba of Katanga, and Bayeke) against the threat of "strangers," mostly from Kasai (Lulua and Baluba from Kasai) recruited by the Union Minière du Haut Katanga (UMHK) to work in the mines. The creation of CONAKAT was triggered by the outcome of the communal elections of December 1957 in which none of the four elected leaders was an "authentic Katangan." 
Three were from Kasai and one from Kivu. The xenophobia of native Katangans in regard to ethnic "strangers" was promoted by urban mining workers seeking to protect their employment as well as the political elite (led by Tshombe) seeking to advance their political agenda.

(iii) Disputes over constitutional orientation: unitarism, federalism, and secessionism

Disputes about the constitutional orientation of the country were a central factor giving rise to the Katangan secessionist movement, and generated antagonism within the national political elite and between nationalists and Belgium. The Loi Fondamentale, the transitional constitution of the country at independence, provided for a parliamentary democracy that ceded substantial autonomy to the provinces. The constitution left significant ambiguity with regard to the division of power between the president and the prime minister and with regard to the control of the central authority over provincial administrations. Provincial leaders exploited these ambiguities to advance their political interests.

Prime Minister Lumumba and his party advocated a unitary and centralized Congo state as the expression of true national independence. In contrast, Lumumba's opponents, led by CONAKAT president Tshombe, wanted secession or at least broad independence of the provinces from the central government. Tshombe believed that provincial sovereignty was a means of achieving fair distribution of resources based on each province's needs and contribution to national wealth. Tshombe stated: "We want a relation between development and people, a share on the basis of the contribution to the development and to the needs created by it" (Gérard-Libois, 1963: 47). Kasavubu, 
president of the country and of the Alliance of the Bankongo (Alliance de Bakongo, ABAKO), also shared Tshombe's views, supported the organization of the Congo into a federal system, and at times threatened secession.

(iv) Relations with Belgium and the West

Lumumba's view was that the independent Congo should cooperate with its former colonizer and other Western countries on an equal footing while preserving national sovereignty. In contrast, Tshombe wanted to keep a patrimonial relationship with Belgium: "Whether a federal Congo with a Katanga state is possible or not, Katanga in any case seeks community with Belgium" (Gérard-Libois, 1963: 33). Tshombe was used as a straw man by Belgium to advance neocolonial interests.

Lumumba's nationalist views attracted animosities from the Belgian government as well as from Belgian financial interests. His socialist leanings generated antagonism from Western powers, including the United States and even the United Nations. This nationalism ultimately cost him his life as he was seen as an obstacle to Belgian neocolonialism and a threat to the Western anti-communism agenda in Africa.

(v) Trigger factors of the secessionist war

Congolese soldiers had expected that, following independence, they would replace Belgians in leadership positions. This was a change which Belgians were not ready to accept. On 5 July 1960, Gérard Jansens, commander-in-chief of the Congolese army, declared that there was no question of Africanizing the command of the army: "Before independence $=$ after independence," he said (De Witte 2001: 6). Following a 
special meeting of the Council of Ministers on July 8, Lumumba took steps to Africanize the officer corps, naming Kasaian Victor Lundula as commander-in-chief of the army (named Armée Nationale Congolaise, ANC), Colonel Joseph Désiré Mobutu as chief of staff, and the Belgian Colonel Henniquian as chief adviser of the ANC.

On July 8, Congolese elements of the ANC in Kongolo revolted against their Belgian officers. The following day, Congolese civilians in Kabolo tried to stop the departure of a train evacuating Belgians. Panic rose among Europeans, and Belgium decided to employ forces to evacuate Belgian nationals.

Tshombe seized the moment to declare the autonomy of Katanga. He argued that he needed to restore order to prevent the political chaos in the central government from disrupting Katanga's economic and administrative system. On July 11, despite attempts by some Belgian officials to dissuade him, Tshombe proclaimed the total independence of Katanga, but kept in place economic ties with Belgium. Although the Belgian government did not officially recognize the Katangan secession, it nonetheless strongly supported Tshombe's government militarily, financially, and diplomatically (Gibbs 1991). Belgian troops prevented attacks by the ANC against Katanga, and Belgium established consular relations with Tshombe's government.

Lumumba's appeal for assistance from the United Nations was ignored. Instead, Belgium, the United States, and the United Nations took advantage of the Katangan secession to undermine Lumumba's regime. Lumumba threatened to call for help from countries of the Socialist bloc. Western governments reached the conclusion that no proWestern government could come to power in the Congo with Lumumba in office (or in opposition, given his strong popular support). It was then decided that Lumumba had to 
be eliminated physically; he was assassinated on 17 January 1961 in a plot orchestrated by Belgians. ${ }^{3}$

After Lumumba's death, the Belgian attitude toward Katangan secession changed significantly. The Belgian government held the position that the integrity of the Congolese territory had to be preserved in a federal system. However, Tshombe refused to participate in the post-Lumumba government led by Ileo. Tshombe's insistence on separation caused the diplomatic isolation of his Katangan government.

In addition to diplomatic isolation, the Katangan secession was handicapped by the antagonism between the self-declared "authentic Katangese" and other ethnic groups, especially the Baluba from northern Katanga. In January 1961, the Association of the Luba People of Katanga (BALUBAKAT) proclaimed the secession of Northern Katanga. On 21 February 1961, the United Nations passed a resolution calling for measures to stop the war in the Congo by authorizing the use of force if necessary. United Nations forces eventually defeated Tshombe's rebels in January 1963.

\subsection{The Kasai secession war: 8 August 1960 - 2 February 1962}

The secessionist movement in the Kasai has some similarities with that of Katanga. It was primarily driven by three interrelated factors: the Lulua-Baluba (Kasai) conflict, ideological divergence between Lumumba and Kalonji (a Muluba) over the constitutional orientation of the country (unitary vs. separatism), and the struggle for the control of mineral resources in the Kasai region. 


\section{(i) Mineral resources}

Known as the "diamond state," southern Kasai has large reserves of both gem quality and industrial diamonds. Until the mid-1970s, the Congo was the single largest producer of industrial diamonds, averaging about one-third of world total output (Kaplan 1978: 224). However, unlike Katanga, the Kasai region did not have longstanding backing from a Belgian settler community. Therefore, it received no support from the West.

\section{(ii) Ideological differences}

The Kasai secession was led by Albert Kalonji, one of the prominent founders of the MNC along with Lumumba. The MNC split in two factions in July 1959 over political differences between Lumumba, on the one hand, and the moderate leaders Ileo and Ngalula and trade union leader Cyrille Adoula, on the other hand. These dissidents accused Lumumba of communistic and autocratic tendencies. As their attempts to replace party president Lumumba with Albert Kalonji failed, they formed a separate wing of the MNC led by Kalonji. The dissident wing became known as MNC-Kalonji, in opposition to MNC-Lumumba. Kalonji espoused Tshombe's opposition to a centralized system.

\section{(iii) The Lulua-Baluba ethnic conflict}

The Kasai secession can be traced to the territorial expansion of the Baluba beyond southern Kasai to the Lulua area in the late-nineteenth century, which created animosities between the Baluba and the Lulua. Because of scarcity of cultivable land, the 
Baluba moved to Luluabourg (in Lulua land) in the early 1920s and eventually dominated most clerical colonial jobs. The fear of domination by the Baluba prompted the creation of the Association of Lulua-Frères in 1951 by a Lulua chief, Sylvain Mangole Kalamba.

The antagonism between the Lulua and Baluba was exacerbated in December 1957 when the Baluba won the municipal elections in Luluabourg (today's Kananga). In 1959, the Lulua regrouped and won the legislative elections, thus securing the majority in the provincial parliament.

The relationship between Baluba and Lulua reached a crisis when the local administration proposed to resettle Baluba farmers from Lulua land (an economically booming center province) back to their impoverished homeland in southern Kasai. This provoked a reaction from the Baluba that escalated into the first deadly conflict on 11 October 1959.

The government sent an investigative team to the area and organized a conference between government representatives and leaders of the two ethnic groups. At the conference it was suggested that some 100,000 Baluba should return from Lulua land to their homeland in southern Kasai to avoid further conflict. While a large number of Baluba moved to southern Kasai, tension continued to escalate.

Kalonji was disappointed by MNC-Lumumba's support of the Lulua in Kasai. Until the latter part of 1959, the MNC-Lumumba had kept a neutral stand in the conflict between Lulua and Baluba. However, in a bid to secure majority seats in the Kasai legislative assembly, the MNC-Lumumba entered into an alliance with the Lulua and defeated the MNC-Kalonji (Lemarchand 1964: 209; CRISP 1962). 
Kalonji exploited these local tensions and the chaos in the central government to declare the secession of southern Kasai. The secessionist war was eventually put down in February 1962 by government forces after some 3,000 to 7,000 thousand people were killed. These figures include combat deaths as well as ethnic massacres.

\subsection{The Kwilu rebellion: 22 January 1964 - 31 December 1965}

\section{(i) The political and ideological background}

In the post-Lumumba period, the United Nations invested diplomatic efforts to press for national reconciliation and unification of the Congo (CRISP 1962). The United Nations organized a conference including parliamentarians and leaders of the provincial governments of Katanga, South Kasai, Haut Congo, and Kinshasa in a neutral venue at Lovanium University. From the conference, a new central government was formed led by Adoula, who had unanimous approval from parliament. Adoula formed a diverse government, including such key pro-Lumumbists as Gigenza and Gbenye (CRISP 1963). To appease regionalist demands, the Adoula government submitted to parliament an amendment to the Loi Fondamentale aimed at restructuring the country into 21 autonomous provinces (up from the six provinces initially created by the Loi Fondamentale). The amendment was promulgated on 27 April 1962.

While the Adoula government tried to find a constitutional solution to the political crisis in Congo, the opposition organized itself with the aim of a revolutionary overthrow of the regime. ${ }^{4}$ Pierre Mulele led the Kwilu rebellion while the Conseil National de Libération (National Liberation Council, CNL) organized the eastern rebellion (see further below) ${ }^{5}$ 
One of the most dedicated Lumumba supporters, Mulele, was Secretary General of the radical wing of the Parti Solidaire Africain (PSA) of Gizenga in 1959-1960 and served as Minister of Education in the Lumumba government. He also served as representative of the Gizenga's Stanleyville provincial government in Egypt and in socialist countries. Having sojourned in Peking, Mulele was influenced by Maoist ideology.

At the end of the Stanleyville government in August 1961, Mulele refused national reconciliation and chose exile, during which he perfected his revolutionary ideology and prepared his strategies for organizing a peasant guerilla force. Mulele accused the central government of having sold out to the interests of the West and advocated a second "liberating independence," which attracted enthusiastic support from rural masses.

(ii) Support for the rebellion: Ethnic base with no mineral resource base

Mulele was from the Mbunda ethnic group while Gizenga was an ethnic Mpende, both groups were from the Kwilu province and claimed to be marginalized by the central government. The ethnic orientation of the Mulelist rebellion facilitated recruitment of combatants but also prevented the rebellion from gaining ground beyond the MbundaMpende territory.

Unlike the Katangan and Kasai rebellions, the Kwilu rebellion was not motivated by the control of provincial mineral resources. Thus, the rebellion could not count on external economic interests for support. The war effort was entirely supported by the local population. 
There are no specific factors that triggered the Kwilu rebellion. Upon his return from exile in July 1963, Mulele mobilized and trained his combatants who were subjected to a rigid code of discipline. The Mulelist rebels posed stiff resistance to government troops despite the rudimentary nature of their military equipment. The rebellion was eventually defeated in December 1965, leaving only pockets of isolated resistance in the rural area.

\subsection{The eastern rebellion: 15 April 1964 - 1 July 1966}

\section{(i) The political context}

The Adoula government failed in its mission of national unification and instead became a vehicle of recolonization of the Congo by Belgium via military occupation and control of the economy. Antagonism between the parliament and the government - this time with the president and the prime minister on the same side - led President Kasavubu to suspend the parliament on 29 September 1963 . The same day, opposition nationalist parties opened an extraordinary conference that ended on October 3 with the creation of the CNL whose objective was to overthrow the Adoula government and to achieve "total and effective decolonization of the Congo thus far dominated by a coalition of foreign powers" (Vanderlinden, et al. 1980: 124).

\section{(ii) The ideological factor}

The leaders of the CNL fled to Brazzaville and formed a cartel of Lumumbistnationalist parties, the most important ones being MNC-Lumumba led by Gbenye and PSA led by Gizenga (Vanderlinden, et al. 1980). The CNL had a socialist orientation 
with both pro-Soviet and pro-Chinese leanings. This socialist orientation proved useful in mobilizing the masses against the central government, which was accused of selling out to capitalist interests, but it also prevented the CNL from obtaining foreign assistance.

(iii) Organization of the rebellion

In January 1964, the CNL sent Gaston Soumialot and Laurent Kabila to Burundi with the mission of preparing the rebellion in the east (Kabila in north Katanga and Soumialot in Kivu). On 15 April 1964, the rebellion started in the Ruzizi plain south of Bukavu and a month later, Uvira was under the control of the simba (which means lions), the rebel forces of the Armée Populaire de Libération (Popular Liberation Army, APL) of the CNL. The rebellion drew its forces from the large population of young, uneducated, and unemployed Congolese. The APL advanced quickly with little resistance from the government forces. The simba were believed to possess magic powers acquired from taking a traditional potion that was purported to transform enemy bullets into water (Verhaegen, 1969).

In two months, the rebels conquered northern Katanga, Maniema, Sankuru and the Orientale province. On 5 September 1964, the "people's government" of Stanleyville was installed in Haut Congo, headed by President Gbenye of the MNC-Lumumba who was also president of the CNL. By the end of September, about half of the country was under control of the APL.

The rich endowment in mineral resources of the eastern provinces was a major motivation and source of financing for the rebellion. In this respect, the eastern rebellion has numerous similarities with the secessionist wars of Katanga and southern Kasai. 
Furthermore, like the Katangan, southern Kasai, and Kwilu rebellions, the eastern rebellion was also supported by a large ethnic base dominated by the Bakusu and Batetela.

(iv) Tshombe returns and defeats the rebellion

The Adoula government continued to experience instability and its army was unable to contain the rebellion. The government turned to Tshombe (in exile in Spain) who still had some influence in the Katanga region and had the backing of Belgian officials and private actors. More important, he had contacts with both the CNL and the Adoula government. Tshombe was believed to be the man who could achieve national reconciliation and control the rebellion (Gibbs 1991). He returned on 26 June 1964 and President Kasavubu gave him the mission of forming a transitional government. To the surprise and anger of many, Tshombe's government did not include representatives from key opposition groups, most notably the CNL. Tshombe rallied his former Katangan gendarmes with the assistance of Belgian mercenaries and advisers and with backing from the United States and Belgium. The rebels unsuccessfully tried to use white hostages to stop the advance of Tshombe's forces. Stanleyville was captured on 24 November 1964, but as many as 200 Europeans and some 46,000 Congolese were killed. ${ }^{6}$ The leaders of CNL retreated from the provincial capitals but continued to fight in rural areas. It was only in 1967 that the Orientale province and Maniema province were fully controlled by government forces. The APL retained limited control over some rural areas in southern Kivu (Fizi and Baraka) under the command of Kabila. The rebellion was completely defeated by 1968 . 
2.5 Shaba I (8 March 1977-8 May 1977) and Shaba II (13 May-3 June 1978)

(i) The political context: Mobutu's regime

The Shaba wars were the first major challenges to Mobutu's rule. When Mobutu seized power in 1965, he undertook several initiatives aimed at stabilizing the country and consolidating power. We emphasize four features of Mobutu's rule that are particularly relevant in explaining the causes of civil wars. First, Mobutu sought to build a sense of national identity as a way of consolidating national unity. In 1971, he initiated a radical program known as "authenticity" which aimed at promoting the traditional culture and eliminating Western cultural influence. The name of the country was changed to Zaïre and the names of provinces (Katanga becoming Shaba) as well as major cities were changed to Zairian names.

In the mid-1970s, however, "authenticity" evolved into Mobutuism, which promoted a cult of personality aimed at legitimizing Mobutu's absolutism. To consolidate power, Mobutu fused the party and state institutions and placed members of his ethnic group in key governmental positions and in the parastatal sector. This further alienated the political elite and antagonized interregional and interethnic relations.

Second, Mobutu managed to cultivate strong international support for his regime by taking advantage of the country's vast resources and its strategic position in the Cold War era. He became a vital Western ally in the fight against communism in Africa. Not only did Mobutu's strategy earn him economic and military assistance, it also allowed him to get away with repression and human rights violations. 
Third, starting in 1974, as Mobutu was consolidating his power, he took measures to eliminate the political influence of the army. Four measures are particularly worth emphasizing (see Emizet 2000a and Metz 1996 for details). First, Mobutu replaced the general chief of staff with four chiefs of staff heading four autonomous branches of the security forces (land forces, air force, coast guard, and the gendarmerie). Second, Mobutu continuously expanded the web of competing and overlapping military and security units. His objective was to balance and control the power of these units, while encouraging them to oversee each other and repress potential opposition. ${ }^{7}$ Third, the national army (Forces Armées Zairoise, FAZ) was underpaid, irregularly paid, and under equipped. Not only did this situation reduce the military threat to Mobutu's power, but also it rendered the military ineffective in defending the country.

Fourth, Mobutu deliberately alienated the military politically through the intimidation of officers and cooptation of the most influential ones. In 1974, he nominated the chiefs of staff and the captain general of the armed forces as members of his party's political bureau. Thus, the army became a partner in the regime.

(ii) The economic context: post-Zairianization crisis

The Shaba wars broke out during the post-Zairianization crisis which was characterized by the systematic decline of economic activity. The economy of the Congo underwent four distinct phases following independence: the post-independence growth (1960-1974) that continued the pre-independence growth, ${ }^{8}$ the post-Zairianization crisis of 1974-1978, the period of failed adjustment of 1978-1988, and collapse since 1988 (see Figure 1 and Table 2). 
In the period following independence, the Congo continued to experience moderate growth as in the pre-independence era. The economic activity was boosted by high copper prices, expansion of mineral production, and the introduction of the first IMF-funded economic stabilization program in July 1967.

Starting in November 1973, Mobutu initiated "Zairianization" whereby foreignowned small and medium-size businesses were either nationalized or simply distributed to private individuals. In 1974, Mobutu announced "radicalization," a program allegedly aimed at redressing major economic problems, including unemployment, inflation, social injustice, and individualism. However, radicalization resulted in the nationalization of the remaining large Belgian-owned companies. Mobutu took a further step to complete his control over mineral resources with the creation of the Société Zairoise pour la Commercialisation des Minerais (SOZACOM), which was put in charge of marketing all mineral resources. 


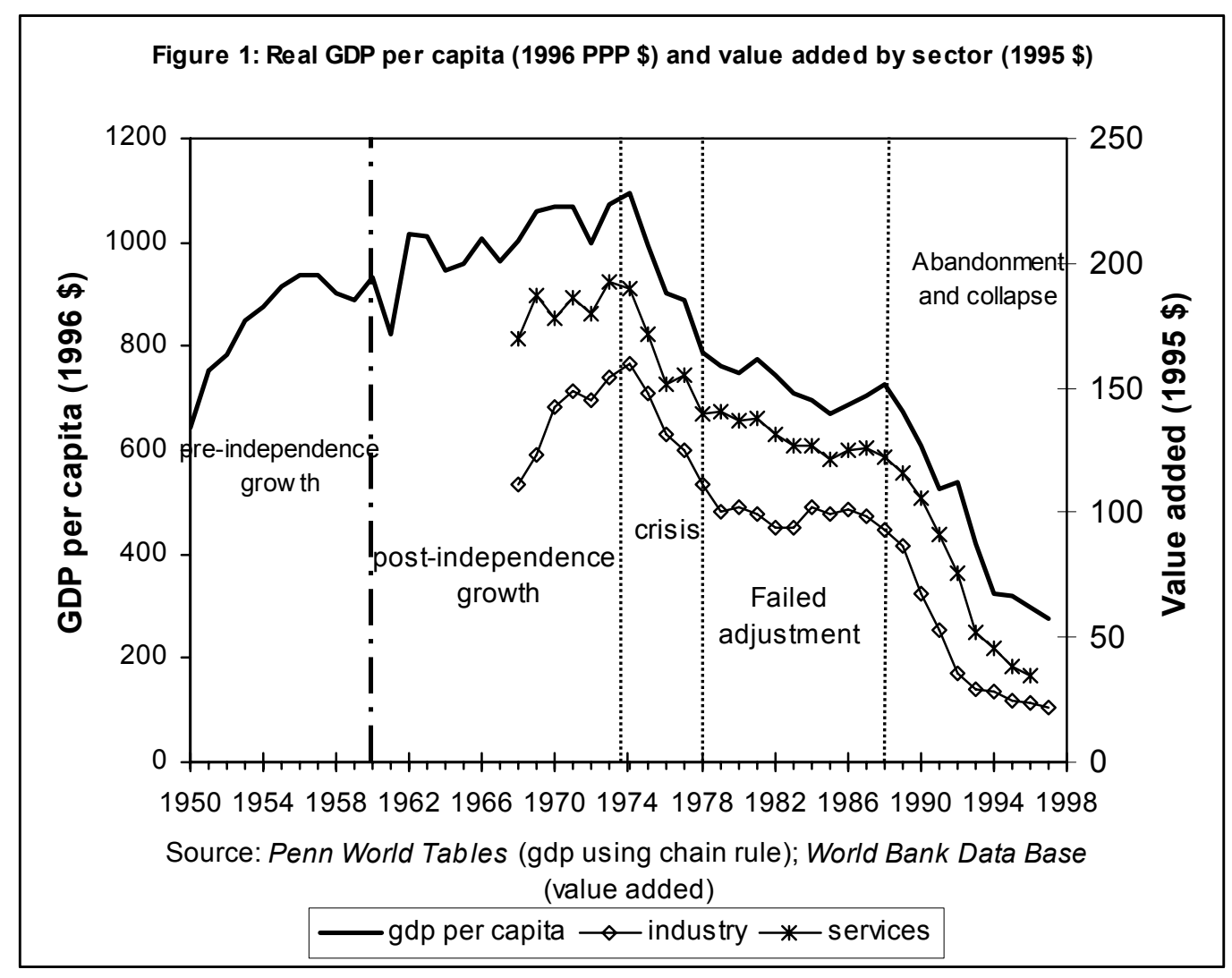

The effects of Zairianization and radicalization were devastating (see Emizet 1997; Young and Turner 1985). Zairianization damaged private sector confidence at home and abroad, undermining international credit worthiness, and thus resulted in a sharp decline in private lending. As private lending declined, Mobutu resorted to bilateral lenders, using his position as a strategic ally of the West. While the government accumulated debt, only a fraction of the debt was actually used to finance economic development as Mobutu and his entourage channeled borrowed funds abroad in the form of capital flight. ${ }^{9}$

In the second half of the 1970s, the Mobutu government undertook several adjustment programs sponsored by the IMF and the World Bank that aimed at reversing the effects of the post-Zairianization crisis and the repercussions of trade shocks. However, the effects of these programs were minimal. Real per capita GDP declined at 
an annual rate of $1.2 \%$ from 1978 to 1988 and inflation continued at an average of $56 \%$ per annum (see Table 2).

(iii) The 1977 invasion in Shaba

A large number of the Katangan gendarmes who fought in Katanga and in the eastern rebellion fled to Angola where they worked for the Portuguese in the fight against liberation movements. With the victory of the MPLA in Angola, the Katangan gendarmes were unemployed and sought to return to the Congo and reclaim their region (now named Shaba) under the banner of the Front for the National Liberation of Congo (Front pour la Libération Nationale, FLNC). Initially, the rebels encountered little resistance from the disorganized, under-equipped, and demoralized government forces. However, before the rebels could capture the mining town of Kolwezi, Mobutu was rescued by Moroccan troops which were airlifted by French aircraft in May 1977.

\section{(iv) The 1978 invasion in Shaba}

After the first Shaba war, Mobutu embarked on a fierce repression mission in which dozens of military officers were hastily tried and handed various sentences ranging from several years in prison to execution. These decisions caused high political tension. In this context of political tension and economic distress, the second Shaba invasion was launched on 3 May 1978 by the former Katangan gendarmes. This time the FNLC declared that its aim was less to conquer Shaba than to remove Mobutu from power. The rebels captured the mining town of Kolwezi on 13 May 1978. 
The United States accused the Soviet Union and Cuba of sponsoring the rebellion, but no evidence corroborated the accusation (Young and Turner 1985). The rest of the country remained relatively calm during the second Shaba war. Mobutu was rescued by a contingent of 700 French troops and 1,700 Belgian soldiers with logistical support from the American Air Force (Young and Turner 1985).

\subsection{The Kabila-led rebellion: 17 October 1996-17 May 1997}

\section{(i) The economic context: Economic collapse and Western disengagement}

In the second half of the 1970s, the Zairian economy continued to deteriorate following the post-Zairianization crisis. In an attempt to avert total economic chaos, the IMF came to the rescue and concluded a new agreement with Mobutu. The IMF forced him to settle the country's debt arrears to the IMF and to bring the IMF-backed Kengo Wa Dondo into the government as prime minister with a mandate to resume structural adjustment. In a concerted effort to give Mobutu another chance, the United States, Belgium, France, and Germany decided to write off portions of the debts owed by Zaïre.

\section{(ii) The political context}

In addition to economic crisis, the Mobutu regime also faced mounting challenges from domestic political opposition. Mobutu's reaction to the opposition's demand for reform was intransigent and violent. In May 1990, when students in Lubumbashi protested against Mobutu's decision to rescind the political reforms announced a month earlier, government troops responded by killing 294 students (Emizet 1997: 44). This further alienated Mobutu in the eyes of his Western allies. In the same year, both the 
United States Congress and the French Government announced that further aid would be conditional upon progress towards democratization. When Mobutu failed to cooperate, the West abandoned him and suspended foreign aid. It is in this context of economic crisis and political chaos that the Kabila-led rebellion broke out in October 1996 and eventually toppled Mobutu's 32-year-long regime in May 1997.

\section{(iii) Trigger factors}

One of the main factors that triggered the rebellion was the influx of more than 1.2 million Rwandan Hutu refugees in June 1994 following the victory by the Tutsi-led Rwandan Patriotic Front (RPF). The refugees included thousands of former Rwandan soldiers and the Interahamwe militiamen who committed the Rwandan genocide.

The influx of Rwandan Hutu refugees had major consequences for the political and security situation in the Congo (Emizet 2000). First, the arrival of refugees altered the ethnic balance in the Kivu region by increasing the marginalization of Banyamulenge traditionally associated with Tutsi origin. By colluding with the Interahamwe, rival "native" ethnic groups took advantage of this opportunity to settle old antagonisms with the Banyamulenge. Second, the presence of armed Hutu refugees in eastern Congo posed a major security threat to the new government of Rwanda.

In an attempt to gather support from "native" Congolese, the Mobutu regime adopted drastic measures against all Kinyarwanda-speaking ethnic groups, the Banyamulenge (comprising only Congolese of Tutsi origin) and the Banyarwanda (comprising both Hutu and Tutsi). ${ }^{10}$ On 28 April 1995, the transitional parliament adopted a resolution that stripped the Banyarwanda and Banyamulenge of their 
Congolese nationality. Then in early October 1996, the deputy governor of South Kivu ordered the Banyamulenge and Banyarwanda to leave the Congo in accordance with the 1995 parliamentary resolution, but they refused to leave and turned to Rwanda for help. The Rwandan government took advantage of this call for help and intervened to resolve the security issue by dismantling the refugee camps, which resulted in the massacre of thousands of Hutu refugees (Emizet 2000b). ${ }^{11}$

This chaotic political situation led to the Alliance des Forces Démocratiques de la Libération (Alliance of Democratic Liberation Forces, AFDL), led by Laurent Kabila, staging a rebellion in eastern Congo in October 1996 with military support from Rwanda, Uganda, and Angola. The AFDL combatants included Banyamulenge and other groups who were opposed to the Mobutu regime such as the Mai Mai. For the Banyamulenge, the main motivation was to defend their rights to nationality. For local "native Congolese," the rebellion was a means of overthrowing the Mobutu regime that had marginalized and repressed them. Social tensions among ethnic groups due to land disputes also contributed to igniting the rebellion.

The rebel forces encountered little resistance from Mobutu's army and were met by cheering crowds as they captured towns en route to Kinshasa. The rebels entered the capital city of Kinshasa on 17 May 1997, and twelve days later, Laurent Kabila was sworn in as the new president of the Congo. 


\subsection{The anti-Kabila rebellion: 2 August 1998 - ongoing}

\section{(i) The political context}

After he took office, Kabila reinforced the ethnic base of the political system by increasing the predominance of people from his native province of Katanga and Congolese of Rwandan descent. The visibility of Banyamulenge in key government positions created resentment among other Congolese. Kabila was seen as an instrument of the political and strategic interests of Rwanda and Uganda.

In late July 1998, Kabila announced the end of military cooperation with Rwanda and Uganda and ordered all foreign troops to leave the country. The Tutsi members of the government felt threatened by this move and left the country immediately. On 2 August 1998, with the help of Rwanda and Uganda, an anti-Kabila revolt broke out, and Kabila's regime was rescued by Angola, Namibia, and Zimbabwe. The anti-Kabila rebellion was strongly opposed by many ethnic groups in Kivu. Many found that whereas the 1996-97 rebellion liberated them from Mobutu, the 1998 rebellion only served the interests of Rwanda and Uganda (International Crisis Group, 2003).

On 16 January 2001, Laurent Kabila was assassinated and his son Joseph Kabila took over the leadership of a country that was partly occupied by rebel troops and foreign forces and suffered from an economy in total chaos. Rwanda and Uganda played a major role in the conflict, directly by the presence of troops on the ground (until they were forced to pull out in 2002), and indirectly by sponsoring specific rebel groups.

(ii) The war and the mineral resource-conflict nexus 
The two wars of the 1990s in the Congo, especially the anti-Kabila rebellion, illustrate the intricate relationships between conflict and mineral resources, and the convergence of domestic and international financial interests in perpetuating conflict. (See Table 3 for details on the main rebel groups involved.) Natural resources provided incentives to fight to capture the resources and helped reduce the constraints in financing war. Once conflict started, various parties derived gains from the conflict through "war economies"; these gains motivated and sustained the continuation of conflict. Exploitation of mineral resources blurred the distinctions between economic and politicomilitary interests as politically unlikely, but economically rational, alliances formed for lucrative purposes. As a result, ending war became less of a priority.

There are many channels through which rebel organizations have been able to finance and sustain the rebellions. The first mode of financing war is direct taxation whereby the armies and rebel forces extract natural resources using soldiers and forced labor. For example, between January and October 2000, coltan exports through comptoirs controlled by the Rassemblement Congolais pour la Démocratie (RCD-Goma) totaled \$6.7 million (International Peace Information Service (IPIS) 2002: 12). Rebels and foreign armies have also financed the war through looting, expropriation, and confiscation of mineral resources and other forms of wealth. Rwandan and Ugandan troops established a monopoly over the exploitation and commercialization of mineral resources by forcing local entrepreneurs out of business while flooding the region with products imported from Rwanda, Uganda, and Burundi (UN Security Council 2001).

Another financing scheme in the anti-Kabila war is the levy of taxes in the rebels' occupied territories. This takes the form of in-kind and direct taxation. For example, the 
RCD collected a tax of about eight percent of total mineral exports by the comptoirs in addition to a $\$ 15,000$ annual license fee per comptoir (IPIS 2002). A fraction of the taxes collected by the RCD was remitted to Kigali and Kampala as payments for military assistance.

Rwanda and Uganda have earned sizable benefits from the exploitation of natural resources in the DRC. Rwanda's receipts in taxes on international trade for 1997-1999 averaged 15.1 billion Rwandan francs, a 31\% increase from 1996 (IMF 2001). The official data from these countries reveal important discrepancies between exports and production (Table 4). Rwanda's coltan exports increased from $\$ 11.4$ million in 2000 to \$44.5 million in 2001, becoming the largest export for the country (Economic Intelligence Unit 2002).

The DRC government in turn has financed its war effort through a scheme referred to as taxe parafiscale, in which state companies are required to hand over a fraction of their profits to the government. The UN Security Council (2001) reported that the Société Minière de Bakwanga (MIBA) turned over 40 percent of its earnings to the government, while the Générale des Carrières et des Mines (GECAMINES) transferred about one-third of its profits to the government.

The anti-Kabila war was also supported by a network of financial institutions based in Rwanda, Uganda, and in developed countries (UN Security Council 2001). Rwandan banks have served as the primary suppliers of the cash dollars used to purchase minerals by local comptoirs and international traders. ${ }^{12}$ The trade of natural resources involves Western banks as well. For example, Banque Bruxelles Lambert of Belgium has handled the financial operations of Aziza Kulsum (alias Madame Gulamali), a 
notorious arms and minerals trader and one-time general manager of RCD-Goma's Société Minière des Grands Lacs (SOMIGL). Citibank of New York also had important indirect financial dealings with rebel groups via their suppliers (UN Panel 2001, paragraph 132).

\section{The case of the Congo and the Collier-Hoeffler model}

\subsection{Predictions of the Collier-Hoeffler model for the Congo}

Using a sample of 161 countries, Collier and Hoeffler (2002) provide estimates of the risk of war over five-year sub-periods from 1960 to 1999. The Collier-Hoeffler model includes proxies of greed and grievance as explanatory factors. The CollierHoeffler "core model" includes the rate of secondary school enrollment of males as one of the explanatory variables; in the "alternative model," this variable is replaced by initial per capita income. Collier and Hoeffler find that three economic factors (greed factors) are robust predictors of the outbreak of civil war: the initial level of income, the growth rate of income, and the share of primary commodity exports in total exports (Collier and Hoeffler 2002: 15). Grievance factors (ethnic dominance and social fractionalization) are found to play a less important role in predicting civil war.

Figure 2 illustrates the predicted probabilities of war for the DRC from the Collier-Hoeffler study, where each year on the horizontal axis is the beginning year of a five-year sub-period. The Collier-Hoeffler model predicts a higher incidence of civil war in the DRC compared to the average in the sample. The probability of war in the DRC ranges from $8 \%$ in the $1975-79$ period to $77 \%$ in the $1995-99$ period compared to an average of $7 \%$ for the sample. 


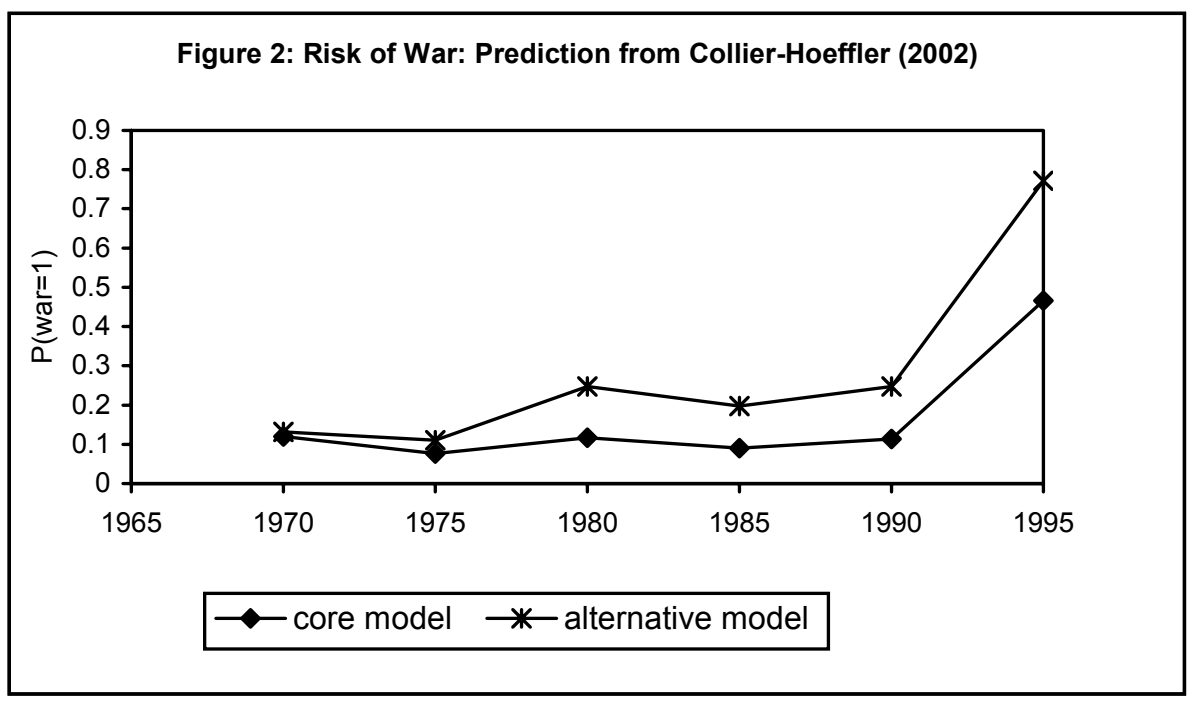

Table 5 presents summary statistics for the regression variables for the DRC and the sample. ${ }^{13}$ Except for ethnic dominance, the factors included in the model make the DRC more prone to civil war than the typical country in the sample. The DRC has lower values for per capita income, income growth (except for 1970-74), and peace duration, while it has higher values for the share of primary commodities in total exports, ethnic fractionalization, population, and geographic dispersion of the population, implying a higher risk of civil war.

Among the factors included in the model, income, its growth rate, and dependence on primary commodities play a central role in causing conflict in the Congo. Low income and low expected economic growth reduce employment and profit expectations, which not only decrease the opportunity cost of joining a rebellion, but also weaken the government's ability to counteract the rebellion.

The dependence on mineral exports makes the DRC prone to conflict due to the struggle for control of resources. The DRC is on the ascending part of the mineral 
resources dependence curve, below the bliss point of 26\% (Collier and Hoeffler 2002: 17). ${ }^{14}$ However, the Collier-Hoeffler model does not account for regional distribution of mineral resources as a mechanism through which mineral resources cause conflict. As discussed in the previous section, it is regional concentration of mineral resources more than resource dependence per se that has made the DRC particularly prone to conflict.

\subsection{The Collier-Hoeffler model and the trend of the risk of war in the DRC}

The Collier-Hoeffler model predicts an increase in the probability of civil war in the 1990-99 period compared to the previous periods, and an even larger increase from 1990-94 to 1995-99. The probability of war jumps from 0.11 to 0.47 in the core model, and from 0.25 to 0.77 in the alternative model between 1990-94 and 1995-99. Thus, the Collier-Hoeffler model fits quite well the 1995-1999 civil wars in the Congo.

Two factors included in the model may explain the increase in the probability of war in the 1990-99 period: per capita GDP and its growth rate. As discussed in Section 2, the economy of the Congo began a collapse in 1988. This would explain the higher risk of war in 1990-94 compared to 1985-89. Income and its growth rate further deteriorated in 1995-99. Per capita GDP dropped from $\$ 442$ to $\$ 375$ (a $15 \%$ decline) while its growth rate worsened from an average of $-3.28 \%$ to $-10.48 \%$ per annum. As Table 5 shows, average per capita GDP in the sample was increasing during that period. None of the other explanatory factors included in the Collier-Hoeffler model experienced large changes that could have caused a significant change in the predicted probability of war in the 1990s. 
Even though the Collier-Hoeffler model correctly predicts a large increase in the risk of war in the 1990s, critical factors that explain this trend are not included in the model. The most important ones are the trigger factors, especially the influx of Rwandan Hutu refugees that disrupted the ethnic balance and exacerbated land disputes in eastern Congo, the military activity of Rwandan militias that induced Rwanda to take an aggressive stand, and the nationality laws that targeted Congolese of Rwandan origin. While economic crisis (captured in the Collier-Hoeffler model by per capita income and its growth rate) created an environment that facilitated the formation of the rebellions, these trigger factors were essential in determining the timing of the onset of rebellions. The role of mineral resources in attracting Ugandan and Rwandan military invasion also explains the higher risk of war in the 1990s. This factor is also not captured in the Collier-Hoeffler model since this is not reflected in the ratio of mineral exports to total exports.

\subsection{Summary: Wars predicted by the Collier-Hoeffler model and puzzles to be explained}

(i) The wars of the 1960s

We do not have war probability estimates for the period of the 1960s due to lack of data.

(ii) The wars of the $1970 \mathrm{~s}$

The Collier-Hoeffler model correctly and systematically predicts a higher risk of war for the Congo than the average country. The deterioration of economic activity, especially following Zairianization, which is accounted for in the Collier-Hoeffler model, was a key 
factor in igniting the rebellions. The struggle for regional control of mineral resources, which is not included in the Collier-Hoeffler model, also played a key role in motivating secessionist movements. A puzzle in this period is that the period 1975-79 has the lowest probability of war in the entire sample period although this period had two wars (the Shaba wars) and was marked by severe economic crisis. The data used in the CollierHoeffler model shows a large decrease in the share of primary exports in total exports from 0.140 to 0.078 . We find no historical explanation for this decrease. The model would naturally predict a decrease in the risk of war as the share of primary exports decreases.

(iii) The 1980s

The higher probability of war in 1980-85 compared to 1975-79 may be explained by the large decline in income (-5.8\% per annum compared to $-1.5 \%$ in the $1975-79$ period; see Table 5) as well as the higher share of primary commodities compared to 1975-79. However, we have no good explanation for the increase in the share of primary commodities in this period. Furthermore, there were no wars in the 1980s. The predictions of the Collier-Hoeffler model for 1980-85 do not seem to be consistent with history.

(iv) The wars of the 1990s

The predictions by the Collier-Hoeffler model of a higher risk of war in the 1990s are consistent with history. The driving factor in the model was the deterioration of economic conditions (proxied by the decline in real per capita income and its growth 
rate). Coincidentally, the struggle for the control of natural resources by domestic and foreign actors, the manipulation of nationality laws, and the influx of refugees, which are factors not formally included in the Collier-Hoeffler model, also increased the risk of war. Therefore, we can conclude that the Collier-Hoeffler model predicts quite well the wars in the 1990s, even though important factors excluded from the model were critical in igniting the rebellions.

\section{Conclusion}

This paper examined the factors that motivated the formation of rebellions, secessionist wars, and civil wars in the Congo since independence. We discussed the predictive power of the Collier and Hoeffler (2002) grievance and greed-based model with regard to the case of the Congo. Some factors included in the Collier-Hoeffler model are important in explaining wars in the Congo, while a number of critical determinants of the timing and location of rebellions are missing from the model.

The level and growth rate of income influenced the risk of conflict, especially through the reduction of the cost of organizing rebellions and also - though to a very limited extent - through the weakening of the government's ability to counteract the rebellions. In the case of the Congo, the government's ability to face the rebellion depended on its external support more than on its own economic capacity.

Natural resource abundance also increased the risk of conflict in the Congo, although the geographic concentration of resources and unequal distribution of wealth provided incentives for secession. The struggle to control mineral resources by domestic and foreign actors also contributed to increasing the risk of war in the 1990s. 
There are important factors that are not formally accounted for in the existing models of civil war that are critical in explaining the timing of rebellions and the risk of conflict in the Congo. Three factors are especially worth emphasizing. First, the identity and nationality laws that targeted Congolese of Rwandan descent helped fuel interethnic tensions in eastern Congo and provided incentives (or a pretext) for the Rwandan and Ugandan regimes to support the rebellions. Second, the influx of Rwandan Hutu refugees in eastern Congo in 1994 disrupted the ethnic balance by marginalizing the Congolese of Rwandan Tutsi affiliation. The third factor is the monolithic nature of the Tutsi-dominated regimes in Burundi and Rwanda and the pro-Tutsi orientation of the Ugandan regime. This factor explains the high sensitivity of these regimes to discrimination against Congolese people of Tutsi affiliation and their readiness to intervene in the Congo. This factor also explains the opposition to the presence of Tutsi elements in Kabila's first government. This opposition arose from the perceived risk of importing ethnic dominance and ethnic conflicts from Burundi and Rwanda.

External political and economic interests played an important role on both sides of the conflict, as some supported the government while others sided with rebel movements. External interests in the Congo were motivated by Mobutu's strategic position in the Cold War geopolitics as well as the country's mineral resources. As the Mobutu regime fell from grace with regards to its external allies in the early 1990s, its capacity to counter the rebellion was severely weakened. Consequently, the rebellions of the 1990s received stronger support from abroad compared to those of the 1960s and 1970s. This explains why the wars of the 1990s have ended either in the victory of the rebellion (in 1996-97) 
or in a military stalemate (since 1998), whereas in earlier wars the government was victorious. 


\section{References}

Askin, Steve and Collins, Carole, 1993. "External Collusion with Kleptocracy: Can Zaire Recapture Its Stolen Wealth?” Review of African Political Economy, 57: 72-85.

Blumenthal, Erwin M., 1982. 'Zaire: Rapport Sur la Crédibilité Financière Internationale,' in Dungia, Emmanuel. Mobutu et l'Argent du Zaire: Les Révélations d'un Diplomate Ex-Agent des Services Secrets (annexe 2), pp. 136-55 (7 April).

Boyce, James K. and Léonce Ndikumana, 2001. "Is Africa a Net Creditor? New Estimates of Capital Flight from Severely Indebted Sub-Saharan African Countries, 1970-96," Journal of Development Studies, 38 (2), 27-56.

Collier, Paul and Anke Hoeffler, 2002. "On the Incidence of Civil War in Africa," Journal of Conflict Resolution, 46 (1), 13-28.

Collier, Paul and Anke Hoeffler, 2001. "Greed and Grievance in Civil War," World Bank, mimeo, (January 4, 2001).

Collier, Paul and Anke Hoeffler, 1998. "On the Economic Incidence of Civil War," Oxford Economic Papers, 50: 563-573.

CRISP, 1962. Congo 1961. Brussels: CRISP.

CRISP, 1963. Congo 1962, Brussels: CRISP.

De Soysa, Indra, 2002. "Paradize Is a Bazaar? Greed, Greed, and Governance in Civil War, 1989-99", Journal of Peace Research, 39 (4), 395-416.

De Witte, Ludo, 2001. The Assassination of Lumumba. New York: Verso.

Economic Intelligence Unit (2002) Rwanda Country Report. London (February 2002).

Emizet, Kisangani, 1997. "Zaire after Mobutu. A case of a humanitarian emergency," UNU/WIDER, Research for Action 32.

Emizet, Kisangani, 2000a. "Explaining the Rise and Fall of Military Regimes: CivilMilitary Relations in the Congo," Armed Forces and Society, 26 (2): 203-227.

Emizet, Kisangani, 2000b. "The Massacre of Refugees in Congo: A Case of UN Peacekeeping Failure and International Law," Journal of Modern African Studies, 38 (2), 163-202.

Emizet, Kisangani, 2001. "Domestic and International Roots of the Congo Conflict: Prospects for Peace and Implications for Post-War Reconstruction," Kansas State University, mimeo (July 30, 2001).

Gérard-Libois, Jules, 1966. Katanga Secession. Madison: University of Wisconsin Press

Gibbs, David N, 1991. The Political Economy of Third World Intervention. Chicago: University of Chicago Press.

Gould, David J., 1980. Bureaucracy, Corruption, and Underdevelopment in the Third World: The Case of Zaire. New York: Pargamon Press.

International Crisis Group, 2003. "The Kivus: The Forgotten Crucible of the Congo Conflict.” ICG Africa Report No. 56, January 2003.

International Peace Information Service, 2002. "Supporting the War Economy in the DRC: European Companies and the Coltan Trade," An IPIS Report (January 2002).

Kaplan, Irving (Ed.), 1978. Zaïre: A Country Study. Washington D.C.: The American University. 
Lemarchand, R., 1964. Political Awakening in the Congo. Berkeley: University of California Press.

Meditz, Sandra W. and Tim Merrill (Eds.), 1994. Zaïre: A Country Study. Washington D.C.: The American University.

Meriam, Alan P., 1961. Congo: Background of Conflict. Evanston, IL: Northwestern University Press.

Metz, Steven, 1996. "Reform, Conflict, and Security in Zaire," mimeo, U.S. Army War College.

Ndikumana, Léonce and James K. Boyce, 1998. "Congo's Odious Debt: External Borrowing and Capital Flight in Zaïre," Development and Change, 29, 195-217.

Ndikumana, Léonce and James K. Boyce, 2003. "Public Debts and Private Assets: Explaining Capital Flight from Sub-Saharan African Countries." World Development, 31 (1), 107-130.

Sambanis, Nicholas, 2002. "A Review of Recent Advances and Future Directions in the Quantitative Literature on Civil War," Defence and Peace Economics, 13 (3): 215-243.

United Nations Security Council, 2001. "Report of the Panel of Experts on the Illegal Exploitation of Natural Resources and Other Forms of Wealth of the Democratic Republic of the Congo," United Nations.

Vanderlinden, J., A. Huybrechts, V.Y. Mudimbe, L. Peeters, D. Van der Steen, B. Verhaegen, 1980. Du Congo au Zaïre 1960-1980: Essai de Bilan. Bruxelles: Centre de Recherche et d'Information Socio-Politiques.

Verhaegen, B., 1969. Rebellions au Congo. Brussels and Kinshasa: CRISP and IRES.

Willame, J. C., 1997. Banyamulenge et Banyarwanda: Viloences Ethniques et Gestion de l'Identitaire au Kivu. Brussels and Paris: Institut African-CédafL'Harmattan.

World Bank, 1980. Zaïre: Current Economic Situation and Constraints. Washington D.C: The World Bank.

World Bank, 2000. World Bank Africa Database, CDROM edition.

World Bank, 2001. World Development Indicators, CDROM edition.

World Bank, 2001. Global Development Finance, CDROM edition.

Young, Crawford, 1965. Politics in the Congo. Princeton: Princeton University Press.

Young, Crawford and Thomas Turner, 1985. The Rise and Decline of the Zairian State. Madison: The University of Wisconsin Press. 

Table 1: Characteristics of wars and rebellions

\begin{tabular}{|c|c|c|c|c|c|c|c|c|}
\hline \multirow{2}{*}{$\begin{array}{l}\text { Name and } \\
\text { duration }\end{array}$} & \multirow{2}{*}{$\begin{array}{l}\text { Prominent } \\
\text { leaders }\end{array}$} & \multirow{2}{*}{$\begin{array}{l}\text { Ideology and } \\
\text { political } \\
\text { objectives }\end{array}$} & \multirow[t]{2}{*}{ Ethnic base } & \multirow{2}{*}{$\begin{array}{l}\text { Size and area } \\
\text { controlled }\end{array}$} & \multirow{2}{*}{$\begin{array}{l}\text { Financing } \\
\text { sources }\end{array}$} & \multicolumn{2}{|c|}{ Foreign support } & \multirow{2}{*}{$\begin{array}{l}\text { Death } \\
\text { toll }\end{array}$} \\
\hline & & & & & & $\begin{array}{l}\text { Support to } \\
\text { rebels }\end{array}$ & $\begin{array}{l}\text { Support to } \\
\text { government }\end{array}$ & \\
\hline $\begin{array}{l}\text { Katanga } \\
\text { secession: } \\
7 / 1960- \\
1 / 1963 \\
\end{array}$ & $\begin{array}{l}\text { Moise } \\
\text { Tshombe }\end{array}$ & $\begin{array}{l}\text { Alleged } \\
\text { federalist; } \\
\text { secessionist in } \\
\text { practice }\end{array}$ & $\begin{array}{l}\text { Lunda-Yeke; } \\
\text { Luba; Bemba }\end{array}$ & $\begin{array}{l}\text { Katanga } \\
\text { region }\end{array}$ & $\begin{array}{l}\text { Mineral } \\
\text { resources; } \\
\text { Belgium }\end{array}$ & $\begin{array}{l}\text { Belgium; } \\
\text { South Africa }\end{array}$ & UN forces & $\begin{array}{l}80000- \\
110000\end{array}$ \\
\hline $\begin{array}{l}\text { Kasai } \\
\text { secession: } \\
8 / 1960- \\
2 / 1962\end{array}$ & Albert Kalonji & $\begin{array}{l}\text { Anti- } \\
\text { Lumumba }\end{array}$ & $\begin{array}{l}\text { Luba-Kasai; } \\
\text { Kuba }\end{array}$ & Kasai region & $\begin{array}{l}\text { Diamonds; } \\
\text { agricultural } \\
\text { resources }\end{array}$ & None & None & $\begin{array}{l}2000- \\
5000\end{array}$ \\
\hline $\begin{array}{l}\text { Kwilu } \\
\text { rebellion: } \\
1 / 1964- \\
12 / 1965\end{array}$ & $\begin{array}{l}\text { Pierre Mulele } \\
\text { (ethnic } \\
\text { Mumbunda); } \\
\text { Louis Kafungu } \\
\text { (ethnic } \\
\text { Mumbunda) }\end{array}$ & $\begin{array}{l}\text { Pro-Marxist; } \\
\text { against } \\
\text { imperialism } \\
\text { and foreign } \\
\text { control of the } \\
\text { economy }\end{array}$ & $\begin{array}{l}\text { Bambunda and } \\
\text { Bapenda }\end{array}$ & Kwilu region & $\begin{array}{l}\text { Fully } \\
\text { supported by } \\
\text { villagers }\end{array}$ & None & None & $\begin{array}{l}3000- \\
6500\end{array}$ \\
\hline $\begin{array}{l}\text { Eastern } \\
\text { Rebellion: } \\
\text { 4/1964- } \\
7 / 1966\end{array}$ & $\begin{array}{l}\text { Gaston } \\
\text { Soumialot; } \\
\text { Christophe } \\
\text { Gbenye; } \\
\text { Nicholas } \\
\text { Olenga; } \\
\text { Laurent Kabila } \\
\text { (section } \\
\text { commander) }\end{array}$ & $\begin{array}{l}\text { Against US- } \\
\text { Belgian } \\
\text { military } \\
\text { invasion and } \\
\text { economic } \\
\text { exploitation }\end{array}$ & $\begin{array}{l}\text { Diverse ethnic } \\
\text { base; } \\
\text { predominance } \\
\text { of Bakusu and } \\
\text { Batetela }\end{array}$ & $\begin{array}{l}\text { South Kivu } \\
\text { and North } \\
\text { Katanga; } \\
\text { Army = Simba }\end{array}$ & $\begin{array}{l}\text { - Own } \\
\text { production of } \\
\text { grenades and } \\
\text { land mines; } \\
\text { - Smuggling } \\
\text { of minerals }\end{array}$ & $\begin{array}{l}\text { - Burundi } \\
\text { (refuge for } \\
\text { rebels; } \\
\text { Commanding } \\
\text { center); } \\
\text { - Algeria, } \\
\text { Sudan, Egypt }\end{array}$ & $\begin{array}{l}\text { USA, } \\
\text { Belgium }\end{array}$ & $\begin{array}{l}200 \\
\text { whites; } \\
\text { over } \\
46000 \\
\text { nationals }\end{array}$ \\
\hline $\begin{array}{l}\text { Shaba I: } \\
\text { 3/1977- } \\
\text { 5/1977 }\end{array}$ & FLNC & $\begin{array}{l}\text { Anti-Mobutu; } \\
\text { anti- } \\
\text { imperialism }\end{array}$ & $\begin{array}{l}\text { Lunda-Yeke; } \\
\text { Luba; Bemba }\end{array}$ & Shaba region & $\begin{array}{l}\text { Mineral } \\
\text { resources }\end{array}$ & Angola & $\begin{array}{l}\text { Morocco, } \\
\text { France }\end{array}$ & $850-1200$ \\
\hline
\end{tabular}


Table 1 (continued): Characteristics of wars and rebellions

\begin{tabular}{|c|c|c|c|c|c|c|c|c|}
\hline \multirow{2}{*}{$\begin{array}{l}\text { Name and } \\
\text { duration }\end{array}$} & \multirow{2}{*}{$\begin{array}{l}\text { Prominent } \\
\text { leaders }\end{array}$} & \multirow{2}{*}{$\begin{array}{l}\text { Ideology and } \\
\text { political } \\
\text { objectives }\end{array}$} & \multirow[t]{2}{*}{ Ethnic base } & \multirow{2}{*}{$\begin{array}{l}\text { Size and area } \\
\text { controlled }\end{array}$} & \multirow{2}{*}{$\begin{array}{l}\text { Financing } \\
\text { sources }\end{array}$} & \multicolumn{2}{|c|}{ Foreign support } & \multirow{2}{*}{$\begin{array}{l}\text { Death } \\
\text { toll }\end{array}$} \\
\hline & & & & & & $\begin{array}{l}\text { Support to } \\
\text { rebels }\end{array}$ & $\begin{array}{l}\text { Support to } \\
\text { government }\end{array}$ & \\
\hline $\begin{array}{l}\text { Shaba II: } \\
7 / 1978- \\
6 / 1978 \\
\end{array}$ & FLNC & $\begin{array}{l}\text { Anti-Mobutu; } \\
\text { anti- } \\
\text { imperialism }\end{array}$ & $\begin{array}{l}\text { Lunda-Yeke, } \\
\text { Luba; Bemba }\end{array}$ & Shaba region & $\begin{array}{l}\text { Mineral } \\
\text { resources }\end{array}$ & Angola & $\begin{array}{l}\text { France, } \\
\text { Belgium, } \\
\text { USA } \\
\end{array}$ & $\begin{array}{l}1000- \\
3500\end{array}$ \\
\hline $\begin{array}{l}\text { Anti-Mobutu } \\
\text { rebellion: } \\
\text { 10/1996- } \\
5 / 1997\end{array}$ & $\begin{array}{l}\text { Laurent Kabila } \\
\text { (with AFDL) }\end{array}$ & $\begin{array}{l}\text { Opposition to } \\
\text { Mobutu } \\
\text { regime }\end{array}$ & $\begin{array}{l}\text { Banyamulenge; } \\
\text { Mai Mai }\end{array}$ & $\begin{array}{l}\text { Large army; } \\
\text { conquered the } \\
\text { country }\end{array}$ & $\begin{array}{l}\text { - Mineral } \\
\text { resources; } \\
\text { Rwanda, } \\
\text { Uganda }\end{array}$ & $\begin{array}{l}\text { Rwanda, } \\
\text { Uganda, } \\
\text { Angola }\end{array}$ & None & $\begin{array}{l}234000- \\
237000 *\end{array}$ \\
\hline $\begin{array}{l}\text { Anti-Kabila } \\
\text { rebellion: } \\
\text { 8/1998- } \\
\text { ongoing }\end{array}$ & $\begin{array}{l}\text { E.W.D. } \\
\text { Wamba; J.P. } \\
\text { Ondekane; J.P. } \\
\text { Bemba }\end{array}$ & Anti-Kabila & Many groups & $\begin{array}{l}\text { Kivu; } \\
\text { Equateur; } \\
\text { Katanga; } \\
\text { Kasai }\end{array}$ & $\begin{array}{l}\text { Mineral and } \\
\text { agricultural } \\
\text { resources }\end{array}$ & $\begin{array}{l}\text { Rwanda, } \\
\text { Uganda }\end{array}$ & $\begin{array}{l}\text { Angola, } \\
\text { Namibia, } \\
\text { Zimbabwe }\end{array}$ & $\begin{array}{l}450000- \\
700000\end{array}$ \\
\hline
\end{tabular}

*This figure includes 232,000 Hutu refugees killed in the Congo (see Emizet 2000b, p. 178). 
Table 2: GDP growth, value added by sector, inflation and budget deficits, 1960-98

\begin{tabular}{|c|c|c|c|c|c|c|}
\hline Period & $\begin{array}{l}\text { Per capita GDP } \\
\text { (annual growth } \\
\% \text { ) }\end{array}$ & $\begin{array}{l}\text { Value added in } \\
\text { agriculture } \\
\text { (annual growth } \\
\% \text { ) }\end{array}$ & $\begin{array}{l}\text { Value added in } \\
\text { industry } \\
\text { (annual growth } \\
\% \text { ) }\end{array}$ & $\begin{array}{l}\text { Value added in } \\
\text { services } \\
\text { (annual growth } \\
\% \text { ) }\end{array}$ & $\begin{array}{l}\text { Inflation (CPI, } \\
\% \text { annual } \\
\text { growth) }\end{array}$ & $\begin{array}{l}\text { Budget deficit } \\
(\% \text { of } G D P)\end{array}$ \\
\hline 1960-1967 & -0.3 & NA & $\mathrm{NA}$ & $\mathrm{NA}$ & NA & $\mathrm{NA}$ \\
\hline $1967-1974$ & 1.5 & -3.3 & 6.2 & 1.9 & 21.4 & $\begin{array}{r}-3.9 \\
(1971-74)\end{array}$ \\
\hline 1974-1978 & -6.5 & -2.7 & -8.5 & -7.3 & 51.2 & -5.6 \\
\hline 1978-1988 & -1.2 & -0.6 & -1.7 & -1.3 & 55.9 & -2.1 \\
\hline 1988-1998 & -7.8 & -0.6 & $\begin{array}{r}-15.8 \\
(1988-96)\end{array}$ & $\begin{array}{r}-14.7 \\
(1988-96)\end{array}$ & $\begin{array}{r}3367.6 \\
(1988-97)\end{array}$ & $\begin{array}{r}-6.1 \\
(1988-97)\end{array}$ \\
\hline
\end{tabular}

Source: Authors' computation using data from World Development Indicators and World Bank Africa Data Base. The growth rates are computed as the annual compounded growth rates between the beginning and the ending year of each sub-period. The figures for inflation and the fiscal deficit are simple averages of annual values.

$\mathrm{NA}=$ data not available 
Table 3: Characteristics of the main rebel movements involved in the anti-Kabila war

\begin{tabular}{|c|c|c|c|c|c|c|c|}
\hline \multirow{2}{*}{$\begin{array}{l}\text { Name and date } \\
\text { of creation }\end{array}$} & \multirow{2}{*}{$\begin{array}{l}\text { Prominent } \\
\text { leaders }\end{array}$} & \multirow{2}{*}{$\begin{array}{l}\text { Ideology and } \\
\text { political } \\
\text { objectives }\end{array}$} & \multirow[t]{2}{*}{ Ethnic base } & \multirow{2}{*}{$\begin{array}{l}\text { Size and area } \\
\text { controlled }\end{array}$} & \multirow{2}{*}{$\begin{array}{l}\text { Financing } \\
\text { sources }\end{array}$} & \multicolumn{2}{|c|}{ Foreign support } \\
\hline & & & & & & $\begin{array}{l}\text { Support to } \\
\text { rebels }\end{array}$ & $\begin{array}{l}\text { Support to } \\
\text { government }\end{array}$ \\
\hline RCD, 1998 & $\begin{array}{l}\text { Ernest Wamba } \\
\text { Dia Wamba; } \\
\text { Jean Pierre } \\
\text { Ondekane }\end{array}$ & $\begin{array}{l}\text { - Unpaid } \\
\text { soldiers in the } \\
\text { East. } \\
\text { - Ethnic } \\
\text { representation in } \\
\text { government } \\
\text { - Ugandan and } \\
\text { Rwandan } \\
\text { interests }\end{array}$ & $\begin{array}{l}\text { Banyamulenge; } \\
\text { former AFDL } \\
\text { fighters }\end{array}$ & $\begin{array}{l}\text { - Large part of } \\
\text { eastern region } \\
\text { - Army base: } \\
11,000 \text { troops in } \\
2002\end{array}$ & $\begin{array}{l}\text { - Mineral } \\
\text { resources }\end{array}$ & $\begin{array}{l}\text { Rwanda, } \\
\text { Uganda }\end{array}$ & $\begin{array}{l}\text { Angola, } \\
\text { Namibia, } \\
\text { Zimbabwe }\end{array}$ \\
\hline MLC, 1998 & $\begin{array}{l}\text { Jean-Pierre } \\
\text { Bemba }\end{array}$ & $\begin{array}{l}\text { - Anti-Kabila } \\
\text { - Ugandan } \\
\text { security and } \\
\text { strategic } \\
\text { interests }\end{array}$ & $\begin{array}{l}\text { Army base = } \\
\text { former Mobutu } \\
\text { presidential } \\
\text { guard }+ \\
\text { members of } \\
\text { Equateur ethnic } \\
\text { groups }\end{array}$ & $\begin{array}{l}\text { - Equateur } \\
\text { region; } \\
\text { - Army base: } \\
5000-10000 \text { in } \\
2002\end{array}$ & $\begin{array}{l}\text { - Diamonds, } \\
\text { gold, timber } \\
\text { - Tax on } \\
\text { diamond trade }\end{array}$ & Uganda & $\begin{array}{l}\text { Angola, } \\
\text { Namibia, } \\
\text { Zimbabwe }\end{array}$ \\
\hline $\begin{array}{l}\text { RCD- } \\
\text { Kisangani, } 1999\end{array}$ & E.W.D Wamba & $\begin{array}{l}\text { - Anti-Kabila } \\
\text { - Uganda and } \\
\text { Rwandan } \\
\text { security and } \\
\text { interests }\end{array}$ & Many groups & $\begin{array}{l}\text { - Kisangani, } \\
\text { Central-Eastern } \\
\text { region } \\
\text { - Army base: } \\
15000 \text { in } 2002\end{array}$ & $\begin{array}{l}\text { - Mineral } \\
\text { resources } \\
\text { - Foreign } \\
\text { financial support }\end{array}$ & Uganda & $\begin{array}{l}\text { Angola, } \\
\text { Namibia, } \\
\text { Zimbabwe }\end{array}$ \\
\hline $\begin{array}{l}\text { RCD-Goma, } \\
1999\end{array}$ & $\begin{array}{l}\text { Emile Ilunga; } \\
\text { Déo Bugera; } \\
\text { Adolphe } \\
\text { Onusumba }\end{array}$ & $\begin{array}{l}\text { - Anti-Kabila } \\
\text { - Ugandan and } \\
\text { Rwandan } \\
\text { interests }\end{array}$ & Many groups & $\begin{array}{l}\text { - North and } \\
\text { South Kivu, } \\
\text { parts of North } \\
\text { Katanga } \\
\text { - Army base: } \\
17000 \text { in } 2002\end{array}$ & $\begin{array}{l}\text { - Mineral } \\
\text { resources } \\
\text { - Foreign } \\
\text { financial support }\end{array}$ & Rwanda & $\begin{array}{l}\text { Angola, } \\
\text { Namibia, } \\
\text { Zimbabwe }\end{array}$ \\
\hline
\end{tabular}

Acronymes: $\mathrm{CNL}=$ Conseil National de la Libération; $\mathrm{AFDL}=$ Alliance des Forces Démocratiques pour la Libération du Congo-Zaire; $\mathrm{RCD}=\mathrm{Rassemblement}$

Congolais pour la Démocratie; MLC = Mouvement pour la Libération du Congo. Since 2002, RCD-Goma split into 3 factions: RCD-Originel, RCD-Authentique, RCD-

Congo. 
Table 4: Mineral exports by Rwanda and Uganda, 1994-2000

\begin{tabular}{|c|c|c|c|c|c|c|c|}
\hline Year & \multicolumn{3}{|c|}{ Gold production and exports } & \multicolumn{2}{|c|}{ Coltan exports } & \multicolumn{2}{|c|}{$\begin{array}{l}\text { Rough diamonds } \\
\text { exports }\end{array}$} \\
\hline & \multicolumn{2}{|c|}{ Uganda } & \multirow{2}{*}{$\begin{array}{l}\text { Rwanda } \\
\text { Production } \\
(\mathrm{kg})\end{array}$} & Uganda & Rwanda & Uganda & Rwanda \\
\hline & $\begin{array}{l}\text { Production } \\
\text { (tons) }\end{array}$ & $\begin{array}{l}\text { Exports } \\
\text { (tons) }\end{array}$ & & \multirow[b]{2}{*}{ na } & \multirow[b]{2}{*}{ na } & \multirow[b]{2}{*}{ na } & \multirow[b]{2}{*}{ na } \\
\hline 1994 & 0.002 & 0.22 & & & & & \\
\hline 1995 & 0.002 & 3.09 & $\overline{1}$ & na & 54 & na & na \\
\hline 1996 & 0.002 & 5.07 & 1 & na & 97 & na & na \\
\hline 1997 & 0.006 & 6.82 & 10 & 2.57 & 224 & 198 & 720 \\
\hline 1998 & 0.008 & 5.03 & 17 & 18.57 & 224 & 1440 & 17 \\
\hline 1999 & 0.005 & 11.45 & 10 & 69.50 & 122 & 1813 & 439 \\
\hline 2000 & 0.004 & 10.83 & 10 & na & 83 & 1263 & 1788 \\
\hline
\end{tabular}

Source: United Nations Security Council (2001), Report of the Panel of Experts on the Illegal Exploitation of Natural Resources and Other Forms of Wealth of the Democratic Republic of the Congo, (12 April 2001). 
Table 5: Means of variables in the Collier-Hoeffler model for the DRC and the sample

\begin{tabular}{l|rrrrrrrrr}
\hline Year & $\begin{array}{r}\text { pgdp } \\
\text { sample }\end{array}$ & $\begin{array}{r}\text { pgdp } \\
\text { DRC }\end{array}$ & $\begin{array}{r}\text { gdpcap } \\
\text { sample } \\
\text { (weighted) }\end{array}$ & $\begin{array}{rrrrr}\text { gdpcap } \\
\text { DRC }\end{array}$ & $\begin{array}{r}\text { gy1 } \\
\text { sample }\end{array}$ & $\begin{array}{r}\text { gy1 } \\
\text { DRC }\end{array}$ & $\begin{array}{r}\text { sxp } \\
\text { sample } \\
\text { (weighted) }\end{array}$ & $\begin{array}{r}\text { sxp } \\
\text { sample } \\
\text { (simple) }\end{array}$ & $\begin{array}{r}\text { sxp } \\
\text { DRC }\end{array}$ \\
\hline 1960 & - & - & 2163 & 489 & - & - & 0.044 & 0.158 & 0.076 \\
1965 & 0.094 & - & 2518 & 548 & 2.71 & 2.28 & 0.046 & 0.162 & 0.076 \\
1970 & 0.067 & 0.131 & 2968 & 686 & 3.19 & 4.49 & 0.047 & 0.165 & 0.140 \\
1975 & 0.070 & 0.111 & 3236 & 637 & 2.42 & -1.48 & 0.057 & 0.183 & 0.078 \\
1980 & 0.070 & 0.247 & 3630 & 476 & 2.22 & -5.82 & 0.073 & 0.201 & 0.112 \\
1985 & 0.061 & 0.197 & 3799 & 442 & -0.43 & -1.48 & 0.056 & 0.154 & 0.131 \\
1990 & 0.058 & 0.248 & 3836 & 375 & 0.81 & -3.29 & 0.049 & 0.146 & 0.141 \\
1995 & 0.064 & 0.772 & 4188 & 222 & 0.37 & -10.48 & 0.048 & 0.142 & 0.141 \\
\hline
\end{tabular}

\begin{tabular}{|c|c|c|c|c|c|c|c|c|c|c|}
\hline year & $\begin{array}{r}\text { frac } \\
\text { sample }\end{array}$ & frac $D R C$ & $\begin{array}{r}\text { etdo } 4590 \\
\text { sample }\end{array}$ & $\begin{array}{r}\text { etdo } 4590 \\
D R C\end{array}$ & $\begin{array}{r}\text { peace } \\
\text { sample }\end{array}$ & $\begin{array}{c}\text { peace } \\
D R C\end{array}$ & $\begin{array}{l}\text { Inpop } \\
\text { sample }\end{array}$ & $\begin{array}{r}\text { lnpop } \\
D R C\end{array}$ & $\begin{array}{l}\text { geogia } \\
\text { sample }\end{array}$ & $\begin{array}{r}\text { geogia } \\
D R C\end{array}$ \\
\hline 1960 & 1777 & 5940 & 0.47 & 0 & 157 & 172 & 14.98 & 16.54 & 0.57 & 0.61 \\
\hline 1965 & 1777 & 5940 & 0.47 & 0 & 213 & - & 15.09 & 16.68 & 0.57 & 0.61 \\
\hline 1970 & 1777 & 5940 & 0.47 & 0 & 263 & 51 & 15.21 & 16.82 & 0.57 & 0.61 \\
\hline 1975 & 1783 & 5850 & 0.47 & 0 & 301 & 111 & 15.32 & 16.96 & 0.57 & 0.61 \\
\hline 1980 & 1788 & 5850 & 0.47 & 0 & 354 & 171 & 15.41 & 17.11 & 0.57 & 0.61 \\
\hline 1985 & 1788 & 5850 & 0.47 & 0 & 415 & 231 & 15.51 & 17.27 & 0.57 & 0.61 \\
\hline 1990 & 1788 & 5850 & 0.47 & 0 & 454 & 291 & 15.61 & 17.44 & 0.57 & 0.61 \\
\hline 1995 & 1788 & 5850 & 0.47 & 0 & 468 & 9 & 15.70 & 17.59 & 0.58 & 0.63 \\
\hline
\end{tabular}

Source: Author's computations from data obtained from Anke Hoeffler.

Variables: pgdp = predicted probability; gdpcap = per capita GDP; gy1 = lagged GDP growth rate; sxp = share of primary commodities in exports; frac = ethnolinguistic fractionalization; etdo4590 = ethnic dominance; peace $=$ peace duration before war; $\operatorname{lnpop}=\log$ of population; geogia $=$ geographic dispersion of the population. 
Table A1: Population by province in 1955

\begin{tabular}{|c|c|c|c|c|}
\hline Province & \multicolumn{3}{|c|}{ Population (and \% of total) } & Relevant features of the province \\
\hline & African & $\begin{array}{l}\text { Non- } \\
\text { African }\end{array}$ & $\begin{array}{l}\text { Wage } \\
\text { earners } \\
(\%)\end{array}$ & \\
\hline $\begin{array}{l}\text { Bas Congo / } \\
\text { Leopoldville }\end{array}$ & $\begin{array}{r}2880762 \\
(23.4)\end{array}$ & $\begin{array}{l}27203 \\
(29.3)\end{array}$ & 27.7 & $\begin{array}{l}\text { - Home of Bakongo ethnic group } \\
\text { - Rapid industrialization } \\
\text { (Leopoldville) }\end{array}$ \\
\hline Equateur & $\begin{array}{r}1690993 \\
(13.7)\end{array}$ & $\begin{array}{l}5453 \\
(5.9)\end{array}$ & 21.6 & $\begin{array}{l}\text { - Remote, marginal political and } \\
\text { economic development }\end{array}$ \\
\hline Kasai & $\begin{array}{r}2029486 \\
(16.4)\end{array}$ & $\begin{array}{l}6881 \\
(7.4)\end{array}$ & 12.0 & $\begin{array}{l}\text { - "Diamond state" } \\
\text { - Home of Kalonji } \\
\text { - Antagonism between Lulua and } \\
\text { Baluba }\end{array}$ \\
\hline Katanga & $\begin{array}{r}1456383 \\
(11.8)\end{array}$ & $\begin{array}{l}28457 \\
(30.7)\end{array}$ & 32.6 & $\begin{array}{l}\text { - Home of Tshombe } \\
\text { - Mining and industrial } \\
\text { development } \\
\text { - Affinity between white } \\
\text { population in Katanga and the } \\
\text { white colonists of northern } \\
\text { Rhodesia }\end{array}$ \\
\hline Kivu & $\begin{array}{r}1948089 \\
(15.8)\end{array}$ & $\begin{array}{l}11266 \\
(12.1)\end{array}$ & 19 & $\begin{array}{l}\text { - "White highlands" of the Congo } \\
\text { (attracting white settlers) } \\
\text { - Powerful kingdoms }\end{array}$ \\
\hline Orientale & $\begin{array}{r}2331613 \\
(18.9)\end{array}$ & $\begin{array}{l}13500 \\
(14.6)\end{array}$ & 23 & $\begin{array}{l}\text { - Home of Lumumba } \\
\text { - Rapid urbanization (Stanleyville) }\end{array}$ \\
\hline TOTAL & 12317326 & 92760 & & \\
\hline
\end{tabular}

Sources: Meriam, Alan P., 1961. Congo: Background of Conflict. Evanston, IL:

Northwestern University Press. Gérard-Libois, Jules, 1966. Katanga Secession. Madison:

University of Wisconsin Press 
1 See Emizet (2001) for further details on these eight wars and other smaller rebellions that are not covered in this study. See Sambanis (2002) for a survey of the theory and empirical evidence on the causes of civil wars. Also see de Soysa (2002) for a discussion of the Collier-Hoeffler model and its predictions.

${ }^{2}$ We do not offer war probability estimates based on the Collier-Hoeffler model for the period of the 1960 s do to lack of data

3 In January 2002, 41 years after Lumumba’s assassination, Belgium officially acknowledged and apologized for its responsibility in the assassination of Lumumba. Needless to say, most Congolese regard the apology as a tardy, meaningless diplomatic act. Nevertheless, Lumumba and his ideology remain a galvanizing force among opposition movements that seek to project a nationalistic image.

${ }^{4}$ On 10 January 1964, a Constitutional Commission held meetings under the leadership of Ileo and adopted a law to be submitted to a referendum. The project proposed a change of the name of the country to Democratic Republic of Congo, officially established the 21 provinces as autonomous entities, made the President head of the executive branch, and limited control by the Parliament over the government in that cabinet members, once confirmed by the Parliament, were answerable only to the President.

${ }^{5}$ Refer Verhaegen (1969).

${ }^{6}$ De Witte $(2001,164)$ provides a figure of 200,000 deaths. This number seems quite incorrect because most people in the Kwilu and eastern Congo welcomed the rebels 
as they were praising Lumumba. The rebels mostly targeted bureaucrats whom they accused of taxing them. The rebellion itself was against the establishment.

${ }^{7}$ The main security units were the Forces Armées Zairoise (FAZ, the regular army), the French-trained $31^{\text {st }}$ Parachute Brigade, and the Israeli-trained Special Presidential Division (DSP). The DSP was regularly paid and was dominated by Mobutu's Ngbandi ethnic group.

${ }^{8}$ The literature often refers to the "growth years" as the period starting with the first IMF adjustment program in 1967 and ending with Zairianization and radicalization in 1974 (World Bank 1980; Kaplan 1978). However, the choice of 1967 as a starting point is not supported by the historical data.

${ }^{9}$ From 1970 to 1996 , the estimated cumulative stock of capital flight from the country amounted to $\$ 19$ billion (see Ndikumana and Boyce 2003; Boyce and Ndikumana 2001). Also see Ndikumana and Boyce (1998), Askin and Collins (1993), Blumenthal (1982), and Gould (1980) for further discussion of capital flight, corruption, and embezzlement of national wealth under the Mobutu regime.

${ }^{10}$ The Banyamulenge are Congolese of Tutsi origin who were separated from Rwanda in 1910, when boundaries of the Belgian Congo were redrawn by the colonial powers (Emizet 2000b). The Banyarwanda include natives of North Kivu (Banyabwisha) separated from Rwanda in 1910, Rwandan Hutu and Tutsi immigrants who arrived in the Congo during the colonial period, and some Tutsi refugees who fled from Rwanda during the 1959 ethnic conflict (Willame 1997). 
${ }^{11}$ Estimates of the number of Hutu refugees killed in eastern Congo vary by source. Some sources estimate that over 200,000 Hutu refugees were killed in the 199697 war (Emizet 2000b).

${ }^{12}$ One of the important financial institutions involved in the trade of natural resources from the DRC is the Banque de Commerce, du Dévelopment et d'Industrie (BCDI) in Kigali. Created in November 1996, BCDI handled most of the financial transactions of the AFDL during the 1996-1997 war.

${ }^{13}$ Per capita GDP values in Table 4 are slightly different from those in Figure 1. Figure 1 reports GDP figures (constant PPP 1996 dollars) from updated Penn World Tables (for the period 1950-97) whereas Table 4 reports data used in the Collier-Hoeffler analysis, that are in 1985 prices from the earlier Penn World Tables (extrapolated for 1989-99). The growth rates of per capita GDP in the two series are very close.

${ }^{14}$ The risk of conflict increases as the mineral resources dependence increases up to a threshold (or bliss point) beyond which risk of conflict declines. 